\title{
Anti-inflammatory and PPAR Transactivational Effects of Components from Ginkgo biloba Seeds
}

\author{
Nguyen Thi Thanh Ngan, ${ }^{\dagger \dagger}$ Tran Hong Quang, ${ }^{\dagger, \star}$ Seok Bean Song, and Young Ho Kim ${ }^{\dagger, *}$ \\ ${ }^{\dagger}$ College of Pharmacy, Chungnam National University, Daejeon 305-764, Korea. *E-mail: yhk@cnu.ac.kr \\ $\$$ Institute of Marine Biochemistry, Vietnam Academy of Science and Technology (VAST), \\ 18 Hoang Quoc Viet, Cau Giay, Hanoi, Vietnam \\ Received March 31, 2014, Accepted May 13, 2014
}

Key Words : Ginkgo biloba seeds, Anti-inflammatory, NF- $\kappa$ B, PPAR

Ginkgo biloba, one of the oldest species of trees, has existed on earth for 200 million years. The G. biloba leaves and seeds have been used in traditional medicine and food for thousands of years. Although numerous pharmacological effects and chemical components of G. biloba leaves extracts have been reported, few studies have been conducted on $G$. biloba seeds. In traditional food and medicine, G. biloba seeds have been used as supplementary materials for desserts, glazed fruits and beverages. ${ }^{1}$ Some studies on the proteins of G. biloba seeds showed that the protein content of dry and defatted G. biloba seed powder was about $7 \%$, and a number of proteins with antifungal and antioxidant activities were isolated..$^{2-5}$ As part of our search for bioactive components from this valuable medicinal plant, ${ }^{6}$ together with the methanol extract of $G$. biloba seeds was found to be active on NF- $\kappa \mathrm{B}$ and PPARs transactivational effects during the preliminary screening process, the present study describes the isolation and structural elucidation of 13 compounds from the methanol extract of G. biloba seeds. The effects of compounds 1-13 on TNF $\alpha$-induced NF- $\kappa$ B transcriptional activity in human hepatocarcinoma (HepG2) cells were evaluated using an NF- $\kappa \mathrm{B}$-luciferase assay. To confirm the inhibitory effects of the compounds on NF- $\kappa \mathrm{B}$ transcriptional activity, the effects of the compounds on the upregulation of the pro-inflammatory proteins iNOS and COX-2 were assessed in TNF $\alpha$-stimulated HepG2 cells by RT-PCR. Futhermore, the effects of compounds 1-13 on the transcriptional activity of PPARs and individual PPAR subtypes in HepG2 cells were also evaluated using a PPRE-luciferase and GAL4-PPAR chimera assays.

The MeOH extract of G. biloba seeds (200 g) was suspended in $\mathrm{H}_{2} \mathrm{O}$ and successively partitioned with $n$-hexane, $\mathrm{CH}_{2} \mathrm{Cl}_{2}$, and EtOAc to give four fractions. The aqueous fraction was subjected to multiple chromatographic steps over Diaion HP-20, silica gel, and reversed-phase $\mathrm{C}_{18}$, yielding compounds 1-13. By comparing the NMR and MS data with those reported in the literature, the structures of the isolated compounds were identified as: $(2 E, 4 E)$-dihydrophaseic acid (1) ${ }^{7}$ rel-5-(1R,5S-dimethyl-3R,4R,8S-trihydroxy-7-oxabicyclo$[3,2,1]$-oct-8-yl)-3-methyl-2Z,4E-pentadienoic acid $(2) ;{ }^{8} 2-$ phenylethyl- $\beta$-D-glucoside (3); ${ }^{9}$ (2R)-3-(4-hydroxy-3-methoxyphenyl)propan-1,2-diol (4); ${ }^{10}$ coniferin (5); ${ }^{11}$ trans-iso- coniferin (6) ${ }^{12}$ trans-ferulic acid 4 - $\beta$-D-glucoside $(7) ;{ }^{13}$ adenosine $(\mathbf{8}) ;{ }^{14}$ thymidine $(\mathbf{9}),{ }^{15}$ cedrusin $(\mathbf{1 0}) ;{ }^{16}$ urolignoside $(\mathbf{1 1}) ;{ }^{17}$ ceplignan-4- $O-\beta$-D-glucoside $(\mathbf{1 2}) ;{ }^{18}$ and $(+)-8-$ hydroxy-pinoresinol 4,4'-di- $O$ - $\beta$-D-glucopyranoside (13). ${ }^{19}$

Compound 1 was isolated as colorless, viscous liquid. The molecular formula of $\mathbf{1}$ was determined to be $\mathrm{C}_{15} \mathrm{H}_{22} \mathrm{O}_{5}$ based on its NMR data and ion peaks on high HRESIQTOFMS: $[\mathrm{M}-\mathrm{H}]^{-}$at $m / z 281.1387$ (calcd. for $\mathrm{C}_{15} \mathrm{H}_{21} \mathrm{O}_{5}, 281.1389$ ) and $[\mathrm{M}+\mathrm{Cl}]^{-}$at 317.1157 (calcd. for $\mathrm{C}_{15} \mathrm{H}_{22} \mathrm{O}_{5} \mathrm{Cl}, 317.1156$ ). The ${ }^{1} \mathrm{H}$ NMR spectrum of $\mathbf{1}$ contained signals for three tertiary methyls at $\delta_{\mathrm{H}} 1.93\left(\mathrm{~s}, \mathrm{H}_{3}-6\right), 1.11\left(\mathrm{~s}, \mathrm{H}_{3}-9^{\prime}\right)$, and $0.89\left(\mathrm{~s}, \mathrm{H}_{3}-\right.$ $\left.10^{\prime}\right)$, and three signals of olefinic protons at $\delta_{\mathrm{H}} 5.81(1 \mathrm{H}, \mathrm{s}$, $\mathrm{H}-2), 7.69$ (1H, d, $J=15.6 \mathrm{~Hz}, \mathrm{H}-4)$, and $6.22(1 \mathrm{H}, \mathrm{d}, J=$ $15.6 \mathrm{~Hz}, \mathrm{H}-5)$. The large coupling constant $(J=15.6 \mathrm{~Hz})$ of the two olefinic protons indicated trans-geometry of the double bond. The ${ }^{13} \mathrm{C}$ NMR and DEPT spectra indicated 15 carbons, including three methyl, three methylene, four methine, and five quaternary carbons. The ${ }^{13} \mathrm{C}$ NMR spectrum of 1 showed the presence of a carboxyl carbon $\left(\delta_{\mathrm{C}} 174.6, \mathrm{C}-1\right)$, two double bonds $\left[\left(\delta_{\mathrm{C}} 127.2, \mathrm{C}-2\right),\left(\delta_{\mathrm{C}} 139.8, \mathrm{C}-3\right),\left(\delta_{\mathrm{C}} 132.1\right.\right.$, $\mathrm{C}-4)$, and $\left.\left(\delta_{\mathrm{C}} 129.2, \mathrm{C}-5\right)\right]$, two oxygenated quaternary carbons $\left[\left(\delta_{\mathrm{C}} 86.8, \mathrm{C}-5^{\prime}\right)\right.$ and $\left.\left(\delta_{\mathrm{C}} 82.2, \mathrm{C}-8^{\prime}\right)\right]$, one oxymethylene $\left(\delta_{\mathrm{C}}\right.$ $\left.76.3, \mathrm{C}-7^{\prime}\right)$, one oxymethine $\left(\delta_{\mathrm{C}} 65.1, \mathrm{C}-3^{\prime}\right)$, and two methylenes $\left[\left(\delta_{\mathrm{C}} 43.5, \mathrm{C}-2^{\prime}\right)\right.$ and $\left.\left(\delta_{\mathrm{C}} 45.0, \mathrm{C}-4^{\prime}\right)\right]$, implying that 1 is a megastigmane. The position of the oxymethylene group at C-7' was assigned from the $\mathrm{HMBC}$ correlation of $\mathrm{H}_{2}-7$ ' to $\mathrm{C}$ 1, C-2', C-5', C-8', and C-1'. The positions of the two double bonds at $\mathrm{C}-2$ and $\mathrm{C}-4$ were assigned by $\mathrm{HMBC}$ correlations of $\mathrm{H}-2$ to $\mathrm{C}-1$, and $\mathrm{C}-6, \mathrm{H}_{3}-6$ to $\mathrm{C}-2, \mathrm{C}-3$, and $\mathrm{C}-4$, and $\mathrm{H}-5$ to $\mathrm{C}-3, \mathrm{C}-4$, and $\mathrm{C}-8$ '. In the NOESY spectrum, the NOE correlations between $\mathrm{H}-2 / \mathrm{H}-4$ and $\mathrm{H}-6 / \mathrm{H}-5$ indicated $E$ geometry of the two double bonds at C-2 and C-4. The NOE correlations between $\mathrm{H}_{3}-10^{\prime} / \mathrm{H}-5$ and $\mathrm{H}_{3}-9^{\prime} / \mathrm{H}-5$ suggested $\alpha$ orientation of the hydroxyl group at $\mathrm{C}-8^{\prime}$ and $\beta$-orientation of $\mathrm{H}_{3}-10^{\prime}$. Moreover, the NOE correlations between $\mathrm{H}_{3}-10^{\prime}$ / H-2' $\beta, \mathrm{H}-5 / \mathrm{H}-2^{\prime} \beta, \mathrm{H}-5 / \mathrm{H}-4^{\prime} \beta, \mathrm{H}-2^{\prime} \alpha / \mathrm{H}-3^{\prime}, \mathrm{H}-3^{\prime} / \mathrm{H}^{\prime} 4^{\prime} \alpha$, and $\mathrm{H}-3^{\prime} / \mathrm{H}-7^{\prime} \beta$ clearly indicated the $\alpha$-orientation of $\mathrm{H}-3$. Based on the above analysis and comparison of the NMR data of 1 with those of a similar compound isolated from the stem

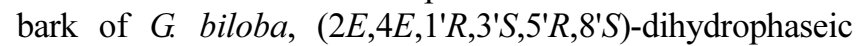
acid $3^{\prime}-O-\beta$-D-glucopyranoside, ${ }^{6}$ the structure of 1 was established as $(2 E, 4 E)$-dihydrophaseic acid. Notably, this is 


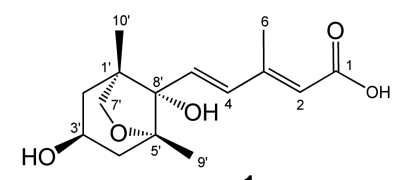

1<smiles>COc1cc(CC(O)CO)ccc1O</smiles><smiles>Nc1ncnc2c1ncn2[C@@H]1O[C@H](CO)[C@@H](O)[C@H]1O</smiles><smiles>CC(=CC=CC1(O)C(C)CC(O)[C@@H](O)C1(C)C)CC(=O)O</smiles>

2<smiles>[R20]CC=Cc1ccc(O[R20])c(OC)c1</smiles>

$$
\begin{array}{ccc} 
& R_{1} & R_{2} \\
5 & \text {-Glc } & H
\end{array}
$$$$
6 \quad H \quad-G l c
$$<smiles>Cc1cn([C@H]2C[C@H](O)[C@@H](CO)O2)c(=O)[nH]c1=O</smiles><smiles>OCCC1(O)OC(OCCc2ccccc2)C(O)C1O</smiles>

3<smiles>COc1cc(/C=C/C(=O)O)ccc1OC1OCC(CO)C(O)O1</smiles>

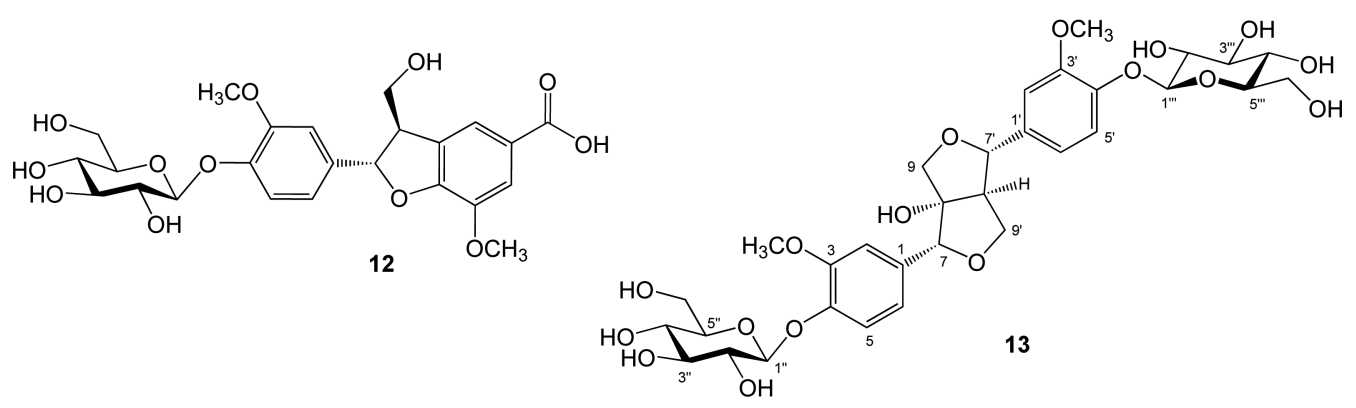

Figure 1. Structures of compounds 1-13.

the first report of NMR data for $(2 E, 4 E)$-dihydrophaseic acid. $^{7}$

Cell viability was evaluated using a 3-(4,5-dimethylthiazol2-yl)-5-(3-carboxymethoxyphenyl)-2-(4-sulfophenyl)-2Htetrazolium (MTS) assay (Promega Celltiter 96-Aqueous One Solution Assay) as described in Supporting information. The result showed that compounds 1-13 had no significant cytotoxicity toward HepG2 cells at the concentration of 10 $\mu \mathrm{M}$ (data not shown).

The anti-inflammatory activity of compounds 1-13 was evaluated through the inhibition of a TNF $\alpha$-induced NF- $\kappa \mathrm{B}$ luciferase reporter and by the attenuation of TNF $\alpha$-induced pro-inflammatory gene (iNOS and COX-2) expression in HepG2 cells. The result showed that compounds 9 and $\mathbf{1 2}$ significantly inhibited TNF $\alpha$-induced NF- $\kappa \mathrm{B}$ transcriptional activity, with $\mathrm{IC}_{50}$ values of 8.7 and $7.1 \mu \mathrm{M}$, respectively (Table 1). Consistent with their inhibitory effects on NF- $\kappa \mathrm{B}$ activation, compounds $\mathbf{9}$ and $\mathbf{1 2}$ significantly inhibited the induction of COX-2 and iNOS mRNA in a dose-dependent manner (Figure 2), suggesting that the compounds reduced the transcription of these genes. Moreover, the housekeeping protein $\beta$-actin was unchanged by the presence of compounds 9 and 12 at the same concentrations.

The effects of compounds 1-13 on PPARs activation were
Table 1. Inhibitory effects of compounds $\mathbf{9}$ and $\mathbf{1 2}$ on the TNF $\alpha$ induced $\mathrm{NF}-\kappa \mathrm{B}$ transcriptional activity

\begin{tabular}{cc}
\hline Compound & $\mathrm{IC}_{50}(\mu \mathrm{M})$ \\
\hline $\mathbf{9}$ & $8.7 \pm 2.5$ \\
$\mathbf{1 2}$ & $7.1 \pm 1.8$ \\
Sufasalazine & $0.9 \pm 0.1$ \\
\hline
\end{tabular}

The values are mean $\pm \mathrm{SD}(\mathrm{n}=3)$. Compounds 1-8, 10, 11 and 13 were inactive at tested concentrations.

evaluated using a PPRE-luciferase reporter assay. The result showed that compounds $\mathbf{4}$ and $\mathbf{1 3}$ significantly activated PPARs transcriptional activity, with $\mathrm{EC}_{50}$ values of 8.5 and

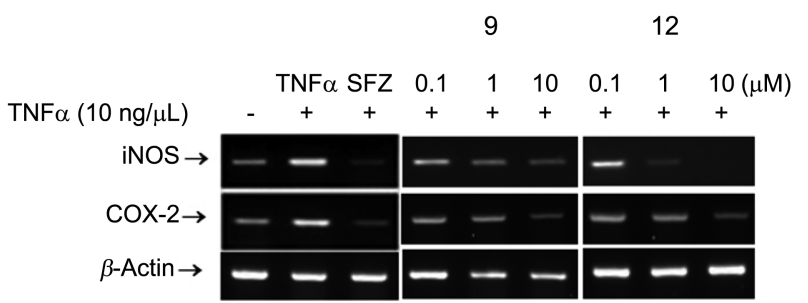

Figure 2. Effects of compounds $\mathbf{9}$ and $\mathbf{1 2}$ on iNOS and COX-2 mRNA expression in HepG2 cells. 
Table 2. PPARs, $\alpha, \gamma$, and $\beta(\delta)$ transactivational activities of compounds 1-13

\begin{tabular}{ccccc}
\hline Compound & \multicolumn{3}{c}{$\mathrm{EC}_{50}(\mu \mathrm{M})$} \\
\hline & $\mathbf{1}$ & Gal4-PPRA $\alpha$-LBD & Gal4-PPRA $\gamma$-LBD & Gal4-PPRA $\beta(\delta)-\mathrm{LBD}$ \\
$\mathbf{2}$ & $22.5 \pm 3.1$ & $>60^{*}$ & $>60$ & n.d. \\
$\mathbf{3}$ & $21.7 \pm 2.5$ & $>60$ & n.d. & $>60$ \\
$\mathbf{4}$ & $8.5 \pm 1.3$ & $>60$ & $>60$ & n.d. \\
$\mathbf{5}$ & $41.6 \pm 4.1$ & $47.7 \pm 2.1$ & n.d. & $>60$ \\
$\mathbf{6}$ & $22.9 \pm 3.2$ & $>60$ & $53.4 \pm 2.6$ & $>60$ \\
$\mathbf{7}$ & $26.8 \pm 2.5$ & $>60$ & $>60$ & $>60$ \\
$\mathbf{8}$ & $26.9 \pm 3.6$ & $>60$ & $50.4 \pm 1.9$ & $52.8 \pm 1.9$ \\
$\mathbf{9}$ & $28.3 \pm 1.8$ & n.d. & $>60$ \\
$\mathbf{1 0}$ & $25.3 \pm 3.9$ & $>60$ & $>60$ & $>60$ \\
$\mathbf{1 1}$ & n.d. & $>60$ & $>60$ & $>60$
\end{tabular}

Bezafibrate

Ciprofibrate

Troglitazone L-165.041
$0.9 \pm 0.2$

$0.8 \pm 0.1$

$\mathrm{EC}_{50}$ : the concentration of tested compound that gave $50 \%$ of the maximal reporter activity. ${ }^{*} \mathrm{~A}$ compound is considered inactive with $\mathrm{EC}_{50}>60 \mu \mathrm{M}$. n.d: not determined

17.0 $\mu \mathrm{M}$, respectively (Table 2 ). Compounds $\mathbf{2}, \mathbf{3}$, and 6-10 displayed moderate activities, with $\mathrm{EC}_{50}$ values ranging from 21.7 to $28.3 \mu \mathrm{M}$. Compound $\mathbf{5}$ weakly activated PPARs transcription, with an $\mathrm{EC}_{50}$ value of $41.6 \mu \mathrm{M}$, whereas compounds 1, 11, and 12 were inactive at the experimental concentrations. Given these primary data, to determine specifically how the compounds modulate PPAR transcriptional activity, we further examined the PPAR transactivational effects of the isolated compounds on individual PPAR subtypes, including PPAR $\alpha, \gamma$, and $\beta(\delta)$. The results indicated that compounds $\mathbf{4}$ and $\mathbf{1 2}$ increased PPAR $\alpha$ transcriptional activity, with $\mathrm{EC}_{50}$ values of 47.7 and $53.3 \mu \mathrm{M}$, respectively. Compounds $\mathbf{6}$ and $\mathbf{8}$ activated PPAR $\gamma$ trascriptional activity, with $\mathrm{EC}_{50}$ values of 53.4 and $50.4 \mu \mathrm{M}$, respectively, whereas compound 9 increased $\operatorname{PPAR} \beta(\delta)$ transcriptional activity, with an $\mathrm{EC}_{50}$ value of $52.8 \mu \mathrm{M}$ (Table 2).

Taken together, this study provides scientific rationale for the use of G. biloba seeds in the prevention and treatment of inflammatory and metabolic diseases and warrants further studies of the potential of G. biloba seeds in functional foods and medicine.

\section{Experimental}

Plant Materials. The seeds of G. biloba were purchased from herbal market at Kumsan, Chungnam, Korea, in August, 2010. The plant material was identified by one of us (Y. H. $\mathrm{Kim})$. A voucher specimen (CNU10110) was deposited at herbarium, College of Pharmacy, Chungnam National University.

Extraction and Isolation. The dried seeds $(10.5 \mathrm{~kg})$ were extracted three times with hot $\mathrm{MeOH}$ under reflux. After concentration, the $\mathrm{MeOH}$ extract (200 g) was suspended in
$\mathrm{H}_{2} \mathrm{O}$ and then partitioned successively with $n$-hexane, $\mathrm{CH}_{2} \mathrm{Cl}_{2}$, and EtOAc to give $n$-hexane (sA, $110 \mathrm{~g}), \mathrm{CH}_{2} \mathrm{Cl}_{2}(\mathrm{sB}, 1.1 \mathrm{~g})$, EtOAc $(\mathrm{sC}, 1.3 \mathrm{~g})$ and aqueous $(\mathrm{sD}, 80 \mathrm{~g})$ fractions, respectively. The aqueous fraction $\mathrm{SD}$ was chromatographed on a column of highly porous polymer (Diaion HP-20) and eluted with a step-wise gradient of $0,30,60$ and $100 \%(\mathrm{v} / \mathrm{v}) \mathrm{MeOH}$ in $\mathrm{H}_{2} \mathrm{O}$ to give four fractions (sD1-sD4). Fraction sD2 (27 g) was separated by YMC RP column chromatography (CC), using $\mathrm{MeOH}-\mathrm{H}_{2} \mathrm{O}(1: 2)$ as eluents to give six subfractions (sD2.1-sD2.6). Compound 9 (7 mg) was isolated by silica gel $\mathrm{CC}$, eluting with $\mathrm{CH}_{2} \mathrm{Cl}_{2}-\mathrm{MeOH}$ (9:1) from subfraction sD2.1 (200 mg). Subfraction sD2.2 was separated by CC over silica gel, eluting with $\mathrm{CH}_{2} \mathrm{Cl}_{2}-\mathrm{MeOH}$ (10:1), and further purified by silica gel $\mathrm{CC}$, using $\mathrm{CH}_{2} \mathrm{Cl}_{2}$-acetone (2:1) as eluents, to obtain compounds $4(9 \mathrm{mg})$ and $\mathbf{2}(6 \mathrm{mg})$. Compound $13(11 \mathrm{mg})$ was isolated by preparative TLC using $\mathrm{CH}_{2} \mathrm{Cl}_{2}-\mathrm{MeOH}-\mathrm{H}_{2} \mathrm{O}$ (4:1:0.1) from subfraction sD2.4 (50 mg). Subfraction sD2.3 (200 mg) was separated by silica gel $\mathrm{CC}$, eluting with $\mathrm{CH}_{2} \mathrm{Cl}_{2}-\mathrm{MeOH}-\mathrm{H}_{2} \mathrm{O}(5: 1: 0.1)$ to give two subfractions sD2.31-sD2.32. Compounds $6(10 \mathrm{mg})$ and 7 (5 mg) were isolated by preparative TLC using $\mathrm{CH}_{2} \mathrm{Cl}_{2}-$ $\mathrm{MeOH}-\mathrm{H}_{2} \mathrm{O}(3: 1: 0.1)$ from subfractions sD2.31 (35 mg) and sD2.32 (42 mg), respectively. Compound 10 (8 mg) was isolated by $\mathrm{CC}$ over silica gel, eluting with $\mathrm{CH}_{2} \mathrm{Cl}_{2}-\mathrm{MeOH}$ (10:1) from subfraction sD2.6 (65 mg). Subfraction sD2.5 (0.3 g) was separated by silica gel $\mathrm{CC}$, eluting with $\mathrm{CH}_{2} \mathrm{Cl}_{2}-$ $\mathrm{MeOH}-\mathrm{H}_{2} \mathrm{O}$ (6:1:0.1) to give two subfractions sD2.51$\mathrm{sD} 2.52$. Compounds $\mathbf{1}(3 \mathrm{mg})$ and $\mathbf{3}(9 \mathrm{mg})$ were isolated by preparative TLC using $\mathrm{CH}_{2} \mathrm{Cl}_{2}-\mathrm{MeOH}-\mathrm{H}_{2} \mathrm{O}$ (4:1:0.1) from subfractions $\mathrm{SD} 2.51(80 \mathrm{mg})$ and $\mathrm{sD} 2.52(66 \mathrm{mg})$, respectively. Fraction sD3 (8 g) was separated by silica gel $\mathrm{CC}$, eluting with $\mathrm{CH}_{2} \mathrm{Cl}_{2}-\mathrm{MeOH}$ (10:1) to provide four subfractions (sD3.1-sD3.4). Compounds 8 (13 mg) and 5 (11 mg) 
were isolated by precipitation and filtered with $\mathrm{MeOH}$ from subfractions $\mathrm{sD} 3.1(100 \mathrm{mg})$ and $\mathrm{sD} 3.2(97 \mathrm{mg})$, respectively. Compounds $11(14 \mathrm{mg})$ and $\mathbf{1 2}(10 \mathrm{mg})$ were isolated by preparative TLC using $\mathrm{CH}_{2} \mathrm{Cl}_{2}-\mathrm{MeOH}-\mathrm{H}_{2} \mathrm{O}$ (4:1:0.1) from subfractions sD3.3 $(170 \mathrm{mg})$ and $\mathrm{sD} 3.4(106 \mathrm{mg})$, respectively.

(2E,4E)-Dihydrophaseic Acid (1): Colorless, viscous liquid; $[\alpha]_{\mathrm{D}}^{25}+16.7(c$ 0.1, MeOH). HRESIQTOFMS: $\mathrm{m} / z$ $281.1387[\mathrm{M}-\mathrm{H}]^{-}$(calcd for $\mathrm{C}_{15} \mathrm{H}_{21} \mathrm{O}_{5}, 281.1389$ ), $\mathrm{m} / \mathrm{z}$ $317.1157[\mathrm{M}+\mathrm{Cl}]^{-}$(calcd for $\mathrm{C}_{15} \mathrm{H}_{22} \mathrm{O}_{5} \mathrm{Cl}, 317.1156$ ). ${ }^{1} \mathrm{H}$ NMR $\left(600 \mathrm{MHz}, \mathrm{CD}_{3} \mathrm{OD}\right) \delta 7.69(\mathrm{~d}, J=15.6 \mathrm{~Hz}, \mathrm{H}-4), 6.22$ (d, $J=15.6 \mathrm{~Hz}, \mathrm{H}-5), 5.81$ (s, H-2), 4.06 (m, H-3'), 3.77 (dd, $\left.J=6.6,1.8 \mathrm{~Hz}, \mathrm{H}^{-} 7^{\prime} \alpha\right), 3.66\left(\mathrm{~d}, J=6.6 \mathrm{~Hz}, \mathrm{H}^{-} 7^{\prime} \beta\right), 1.98$ (m, H-4' $\alpha$ ), 1.93 (s, $\mathrm{H}_{3}-6$ ), 1.80 (m, H-2' $\alpha$ ), 1.72 (dd, $J=13.8$, $\left.10.2 \mathrm{~Hz}, \mathrm{H}-4^{\prime} \beta\right), 1.64$ (m, H-2' $\beta$ ), 1.11 (s, $\left.\mathrm{H}_{3}-9^{\prime}\right), 0.89$ (s, $\mathrm{H}_{3^{-}}$ 10 ); ${ }^{13} \mathrm{C}$ NMR $\left(150 \mathrm{MHz}, \mathrm{CD}_{3} \mathrm{OD}\right) \delta 174.6(\mathrm{C}-1), 139.8(\mathrm{C}-$ 3), 132.1 (C-4), 129.2 (C-5), 127.2 (C-2), 86.8 (C-5'), 82.2 (C-8'), 76.3 (C-7'), 65.1 (C-3'), 48.8 (C-1'), 45.0 (C-4'), 43.5 (C-2'), 19.5 (C-6), 18.7 (C-9'), $15.4\left(\mathrm{C}-10^{\prime}\right)$.

Acknowledgments. This study was supported by Priority Research Center Program through the National Research Foundation of Korea (NRF) funded by the Ministry of Education, Science and Technology (2009-0093815), Republic of Korea.

Supporting Information. The HRESIQTOFMS and NMR spectra of compound $\mathbf{1}$, physicochemical properties of compounds 2-13, and experimental information.

\section{References}

1. Deng, Q.; Wang, L.; Wei, F.; Xie, B.; Huang, F.; Huang, W.; Shi,
J.; Huang, Q.; Tian, B.; Xue, S. Food Chem. 2011, 124, 1458.

2. Huang, W.; Deng, Q.; Xie, B.; Shi, J.; Huang, F. H.; Tian, B.; Huang, Q.; Xue, S. Food Res. Int. 2010, 43, 86.

3. Zhou, H.; Chen, X.; Wang, C.; Ye, J.; Chen, H. Molecules 2012 , $17,14778$.

4. Huang, W.; Xie, B.; Wang, Y.; Yang, E. N.; Luo, R. Sci. Agric. Sinica 2004, 37, 1537.

5. Wang, H.; Ng, T. B. Biochem. Biophys. Res. Commun. 2000, 279, 407.

6. Ngan, N. T.; Quang, T. H.; Tai, B. H.; Song, S. B.; Lee, D.; Kim, Y. H. J. Agric. Food Chem. 2012, 60, 2815.

7. Martin, G. C.; Dennis, F. G., Jr.; MacMillan, J.; Gaskin, P. J. Am. Soc. Hortic. Sci. 1977, 102, 16.

8. Kikuzaki, H.; Kayano, S.; Fukutsuka, N.; Aoki, A.; Kasamatsu, K.; Yamasaki, Y.; Mitani, T.; Nakatani, N. J. Agric. Food Chem. 2004, 52, 344

9. Ali, F.; Iqbal, M.; Naz, R.; Malik, A.; Ali, I. J. Chem. Soc. Pak. 2011, 33, 90.

10. Ouyang, M. A.; Chen, P. Q.; Wang, S. B. Nat. Prod. Res. 2007, 21, 769 .

11. Guvenalp, Z.; Ozbek, H.; Kuruzum-Uz, A.; Kazaz, C.; Demirezer, L. O. Turk. J. Chem. 2009, 33, 667.

12. Nakanishi, T.; Iida, N.; Inatomi, Y.; Murata, H.; Inada, A.; Murata, J.; Lang, F. A.; Iinuma, M.; Tanaka, T. Heterocycles 2004, 63, 2573.

13. Park, B.-J.; Tomohiko, M. Chem. Nat. Compd. 2011, 47, 363.

14. Ciuffreda, P.; Casati, S.; Manzocchi, A. Magn. Reson. Chem. 2007, 45, 781 .

15. Larsen, E.; Aleem, A. A. H. A.; Pedersen, E. B. J. Heterocycl Chem. 1995, 32, 1645.

16. Agrawal, P. K.; Agarwal, S. K.; Rastogi, R. P. Phytochemistry 1980, 19, 1260 .

17. Shen, Y.-C.; Hsieh, P.-W.; Kuo, Y.-H. Phytochemistry 1998, 48, 719 .

18. Jia, L.; Bi, Y. F.; Jing, L. L.; Zhou, S. A.; Kong, D. Y. J. Asian Nat. Prod. Res. 2010, 12, 962.

19. Deyama, T.; Nishibe, S.; Kitagawa, S.; Ogihara, Y.; Takeda, T.; Omoto, T.; Nikaido, T.; Sankawa, U. Chem. Pharm. Bull. 1988, 36,435 . 